Discussion Paper No. 840

\author{
MORE APPLES LESS CHIPS? \\ THE EFFECT OF SCHOOL FRUIT SCHEMES \\ ON THE CONSUMPTION \\ OF JUNK FOOD \\ Giorgio Brunello \\ Maria De Paola \\ Giovanna Labartino
}

April 2012

The Institute of Social and Economic Research

Osaka University

6-1 Mihogaoka, Ibaraki, Osaka 567-0047, Japan 


\title{
More Apples Less Chips? \\ The Effect of School Fruit Schemes on the Consumption of Junk Food
}

\author{
Giorgio Brunello (University of Padova, IZA and Cesifo) \\ Maria De Paola (University of Calabria) \\ Giovanna Labartino (IRVAPP)
}

\begin{abstract}
We use scanner data of supermarket sales to investigate the effects of the EU School Fruit campaign, conducted in a sample of primary schools in the city of Rome during 2010 and 2011, on the consumption of unhealthy snacks. We allocate supermarkets to treatment and control groups depending on whether they are located or not near treated schools and estimate the causal effect of the program by comparing the changes in the sales of snacks in treated stores with the changes in control stores. We find evidence that the campaign reduced the consumption of unhealthy snacks bought in stores located in high income areas. No effect is found in poorer areas. Repeated treatment does not strengthen the effects of the program.
\end{abstract}

Keywords: EU School Fruit campaign, junk food, Rome

JEL Code: I18

Acknowledgements: we are grateful to Giovanni Anania, Daniele Fabbri, Mario Mazzocchi, Lorenzo Rocco and Vincenzo Scoppa for comments and suggestions. Giorgio Brunello and Giovanna Labartino gratefully acknowledge financial support from Fondazione Cariparo. The usual disclaimer applies. 


\section{Introduction}

Policy interventions to counter increasing child obesity in developed countries can be classified as information and market intervention measures. Information measures include information campaigns, advertising regulations, labelling rules and nutritional education programs in schools (see Mazzocchi, Traill and Shogren, 2009). These policies are expected to affect behaviour because they increase awareness and knowledge of the health consequences of eating habits.

Examples of education programs in schools are the 5-a-day fruit and vegetable campaigns carried out in several countries and the EU School Fruit Scheme, which was launched at the end of 2007 and implemented in the following years in a number of member countries. Empirical studies that have tried to evaluate the impact of these policies have found some positive effects, especially in the short run. In a recent review of this literature, Mazzocchi, Traill and Shogren, 2009, conclude that "... the balance of evidence on the effectiveness of information campaigns and social marketing is that they raise awareness but do not affect behaviour ...” (p.119).

Fruit and vegetable campaigns typically combine the distribution of these products in schools with the dissemination of information on correct health lifestyles, which favours the consumption of fruit and vegetables at the expense of junk food such as unhealthy salty and sweet snacks (snacks high in added sugar and/or saturated fat).

While most empirical studies have analyzed whether and how these campaigns have affected the consumption of fruit and vegetables, little has been done to investigate their effects on the consumption of junk food. Yet an increase in the intake of fruits need not suffice to combat overweight and obesity if this increase is not accompanied by a reduction in the intake of high in - calories junk food. Clearly, fruit and vegetable campaigns which increase the intake of these products at the expense of junk food are more valuable for public health than campaigns that only affect the consumption of fruit and vegetables.

In this paper, we study the effects of the European School Fruit campaign on the consumption of unhealthy salty and sweet snacks by using data on the daily sales of these products in a sample of supermarkets located in the city of Rome ${ }^{1}$. Although the consumption of fruit and vegetables in Italy is higher than in Northern European countries, poor nutrition is an important policy issue in this country as well, especially for young people. In Italy, the

\footnotetext{
${ }^{1}$ Unfortunately, our data do not include information on the sale of fruit and vegetables. In Italy, at least 40 percent of the purchases of these products occurs in local markets and at small greengrocers (data from the "Osservatorio dei Consumi Ortofrutticoli delle famiglie italiane"). Therefore, even if we had such data, they would provide a rather partial information on overall consumption.
} 
percentage of obese children has increased from 9 to 12.5 percent in less than ten years and close to one quarter of all children are overweight (National Health Institute, 2010).

Our empirical strategy is a standard differences-in-differences technique, which combines treated schools with neighbouring food retail stores belonging to two large national supermarket chains. We consider as treated the stores located within a radius of 500 meters from treated schools and as controls the stores located outside such radius. For both groups of stores, we compare the daily sales of a broad variety of sweet and salty snacks before and after the education campaign.

The key assumption required for this strategy to work is that the majority of households living in a given area send their children to nearby primary schools and shop at nearby supermarkets. Under such assumption, the effects of the policy show up by comparing the sales of snacks by local and distant supermarkets before and after the treatment. Because we cannot exclude that some households shop also farther away or send their children to more distant schools, and that local schools attract pupils from outside the neighbourhood, our estimates must be interpreted as a lower bound of the true effect. Better strategies would compare consumption before and after the treatment by the households sending their children to treated and control primary schools. The household data required for such comparison must have detailed information on consumption patterns as well as information on the primary school where children go. Typically, these data are not available.

When we focus on the initial treatment (Spring 2010), we find that the campaign has reduced the consumption of unhealthy snacks in treated stores - relative to control stores - by 4.6 percent. This effect is small and not statistically significant, in line with the assessment by Mazzocchi and co-authors. There is also evidence, however, that the impact of the campaign is heterogeneous across locations and store types. When we distinguish between stores located in wealthier and poorer areas of the city, we find that the campaign has been effective in reducing the consumption of snacks only in the treated stores located in wealthier areas. In these stores, the consumption of junk food declined after the treatment by 12 percent, a sizeable and statistically significant effect. In contrast, we do not find any statistically significant decline in the consumption of snacks in the treated stores located in poorer areas.

We further distinguish between regular and discount stores and find that the negative effect of the campaign on the consumption of snacks in wealthier areas of the city is even larger (13.1\%) when we focus on regular stores. The effect is statistically not different from zero in other stores. These heterogeneous effects are not driven by differences in price behavior, as we find that the campaign does not affect the pricing of snacks in treated supermarkets. 
Our evidence also suggests that program effectiveness tends to diminish over time. When we combine the initial treatment in 2010 with the second treatment in 2011, we find that the size of the overall effect is smaller than the effect of the initial treatment, suggesting that an important part of the latter is temporary: as treated consumers get used to the treatment, they partially but not entirely revert to old consumption habits.

If the effects identified by our empirical approach were spurious and did not genuinely reflect the causal impact of the School Fruit campaign, we should find similar effects on unrelated products. Yet, in a placebo experiment using the sales of liquid detergents, which are unlikely to be affected by the campaign, we find no statistically significant effect of the treatment both in the full sample and in the sub-groups of stores located in different areas. We conclude that our estimates are unlikely to capture spurious effects.

A relatively large literature has documented the positive relationship between higher levels of education and better health (see Grossman, 2006, for a survey and Brunello, Fabbri and Fort, 2011, for a recent contribution covering several European countries). As suggested by Cutler and Lleras-Muney (2010), better educated individuals may be more prone to follow healthy behaviours, better informed of the health consequences of bad eating habits and, as a consequence, more sensitive to programs reinforcing this information. Alternatively, individuals with a poor socio-economic background may be more affected by problems of self - control and time inconsistencies, which deter them from translating in good health behaviours the information received through the program (Scharff 2009, Komls et al. 2004).

Since consumers shopping in supermarkets located in high income areas tend to have higher income and better education than consumers shopping in poorer areas and in discount stores, our results can be interpreted as suggesting that the School Fruit campaign has reduced the consumption of junk food in the sub-group of the population who is less likely to be exposed to overweight and obesity problems, but has been not effective at all for the sub-group more at risk. Whether this interpretation holds with better (but yet unavailable) data which include information on household consumption patterns as well as on the schools where children go is an open question that we leave to future research.

The paper is organized as follows. Section 2 presents a brief review of the relevant empirical literature, Section 3 describes the School Fruit campaign as implemented in the primary schools of the city of Rome. Sections 4 and 5 introduce the data and the empirical setup. Results are presented and discussed in Section 6. Section 7 is devoted to a few robustness checks. Conclusions follow. 


\section{Previous Literature}

Since policies that address obesity are fairly recent, empirical evaluations of programs aimed at improving the food habits of children are still relatively rare. In this section, we provide a short review of this literature, without pretending to be exhaustive. A strand of the literature has focused on the effect of school food programs, which impose nutritional requirements to combat childhood obesity. A number of recent studies have analysed the effects of two well known programs implemented in US: the School Breakfast Program (SBP) and the National School Lunch Program (NSLP). Results are, however, rather inconclusive: once non-random selection is taken into account, it emerges that the while the SBP has produced beneficial effects, the NSLP has been detrimental (Schanzenbach, 2009; Bhattacharya, Currie and Haider, 2006; Millimet et al., 2010).

Another strand has investigated the effects of information dissemination on health. Since consumers generally lack information on the nutritional value and caloric content of the food products they consume and are not fully aware of the health consequences of poor eating habits, disseminating information has been included among the objectives of many public programs. These policies include mandatory nutritional labelling and mandatory posting of nutrient content on menus. Again, results are mixed. On the one hand, Bollinger et al. (2010) use a difference-indifferences estimation strategy and show that mandatory calorie posting affects consumer behaviour and reduces the average calories of chosen food in a well know fast food chain. On the other hand, Variyam (2008), Drichoutis et al. (2009) and Elbel et al. (2011) show that these policies do not produce significant effects on consumer food choices and the body mass index. Among the factors contributing to undermine the effects of information dissemination campaigns, a crucial role is played by food industry advertising, which typically affect food preferences (Lobstein and Dibb, 2005; Chou et al. 2008).

Closely related to our work are the papers investigating the effects on consumers of information campaigns promoting the consumption of fruit and vegetables. An important contribution in this area is Capaci and Mazzocchi, 2011, who study the 5-a-day information campaign in the UK and find evidence of positive but small effects on fruit and vegetables consumption, which are partially offset by price increases. Pomerleau et al, 2005, review the evidence on the effectiveness of programs promoting fruit and/or vegetables consumption inadults and report small increases in intakes. De Sa and Lock, 2008, examine 23 studies assessing the impact of school campaigns on children and conclude that these schemes are effective in increasing both knowledge and intake. Finally, Velde and co-authors, 2008, evaluate 
the Pro Children campaigns aimed at promoting the intake of fruit and vegetables in Norway, The Netherlands and Spain and find that these policies are promising but tend to have short term effects and to work especially for fruit.

By and large this literature evaluates the impact of fruit and vegetables campaigns on the consumption of these products but fails to investigate whether the increase in this consumption has been accompanied by the reduction in the intake of unhealthy and calorie intensive junk food, such as salty and sweet snacks, which has strongly increased over time and has today a very important role in the daily diet of children, with negative effects on their health and body weight. Piernas and Popkin, 2010, for instance, show that more than 27 percent of US children's intake of daily calories derives from snacks (mainly salty and high fat snacks). Kerr et al. 2009, on the other hand, use British and Irish data to show that the consumption of snacks is significantly higher among adolescents in 2005 than in 1997. The upward trend in the contribution of snacks to the daily energy intake is confirmed by Ovaskainen et al., 2006, for Finland, by Bellisle et al., 2003, for France and by Marques-Vidal, 2006, for Portugal.

\section{The School Fruit Campaign}

The EU School Fruit campaign was launched in October 2007 to increase children's intake of fruit and vegetables and to promote healthy diet habits and more balanced nutrition patterns. The campaign consists of a) distributing products to children at school; b) providing information on a correct and healthy diet to children, teachers and parents.

In Italy the campaign was implemented by the Italian Ministry of Agriculture jointly with the Ministry of Education and Research. The target group consisted of children aged six to eleven and attending primary school. Implementation started in the Spring of 2010 and continued in the following years, involving about 5000 primary schools all over the country. Participation of schools to the program was on a voluntary basis, broadly on a "first come first served" basis. Schools participating to the first treatment could and typically did join the treatment in the following year, with the only restriction that priority was given to new entrants in the scheme.

The program consisted in the periodical distribution of fruits or vegetables to children during school hours. The period when the distribution took place varied by region, but in most cases started in February and ended in June, when the school year ended. While the varieties of fruit and vegetables distributed were slightly different across regions, the following products were distributed across all schools: oranges, strawberries, kiwi, apples, pears, carrots, fennels and cherry tomatoes. During the treatment period established by the program, every child had to 
consume fruit and vegetables at least 20 times and consumption was expected to include at least 4 different fruit and vegetable products. The program also required teachers to match the distribution of products with information on the benefits of an healthy diet. To favor this combination, the distribution of products never occurred during lunch breaks. To enhance the effectiveness of the campaign, children were also exposed to complementary activities, aimed at promoting awareness of healthy food habits. These actives included visits to farms, working in the school garden, games associated to the consumption of fruit and vegetables, and homework activities focusing on the healthy properties of fruit and vegetables.

In the first two years of the campaign close to 870.000 children were treated in Italy, which corresponds to about $20 \%$ of the population of pupils enrolled in primary schools. In this paper, we focus on the pupils of the primary schools located in Rome, who were exposed to treatment in 2010 and 2011. During the first year, 100 out of 579 schools in the capital city were treated ${ }^{2}$. During the second year, this number increased to 174, with 72 schools participating in both years $^{3}$.

We match treated and untreated schools with supermarkets belonging to two national chains, for which we have data on daily sales of a large variety of salty and sweet snacks high in added sugar and/or saturated fat. Matching is based on distance: we define as treated the stores located within a given radius from a treated school, and as controls the stores located outside such radius. This matching strategy implies that we only consider the sub-sample of treated schools which is located close to at least one supermarket in our list of stores.

As discussed more in detail below, we perform this match for 2010 and 2011 and end up with 44 stores, 15 belonging to the treatment group and 29 to the control group. By selecting for the treatment group the stores located near schools treated both in 2010 and in 2011, we can compare the effects of the first and the second treatment. We exclude from our sample the only store located near a school treated in 2010 but not in 2011, and the stores located near to schools treated in 2011 but not in 2010, because our data end in September 2011, too early to capture the post-treatment effects.

\section{The Data}

Compared to fruit and vegetables, which are sold in Italy also by small greengrocers and local markets, processed food - including salty and sweet snacks - is bought mainly in

\footnotetext{
${ }^{2}$ Data from the "Ufficio Scolastico Regionale" of Lazio, the region where Rome is located.

${ }^{3}$ All the classes in each participating school were involved in the program.
} 
supermarkets ${ }^{4}$. We use scanner data on the daily sales of sweet and salty snacks in the stores of two large Italian supermarket chains (DESPAR and Tuo Discount) operating nationwide. These stores sell different varieties of sweet and salty snacks. We focus on unhealthy sweet and salty snacks with a high content of added sugar and/or saturated fats, such as crisps and pastries, and exclude low calorie snacks. For each variety, we have information on the daily price and quantity sold, the daily stock ${ }^{5}$ and total daily revenues by store. Overall, there are 182 varieties, 96 in the category "sweet snacks” and 86 in the category "crisps". Close to one quarter of these varieties are commercialized as premium products of well known brand manufacturers, and the remaining three quarters are sold at lower prices as generic products with a local brand or no brand at all.

For each variety, we measure the daily quantity sold in pieces. We control in our regressions for the different formats and weights of each variety by using variety dummies. Table 1 shows that the average daily quantity of snacks sold per store during the selected period (2009-2011) was equal to 76.54 pieces (19.25 kilograms) in the 15 stores assigned to the treatment ("treated stores”) and to 110.2 pieces per day (28.16 kilograms) in the 29 stores assigned to control (“control stores”). The average price per piece sold was $€ 1.43$ (1.51 and 1.36 respectively for treated and control stores), and average daily sales of all products were $€ 7,949$ for treated stores and $€ 10,153$ for control stores.

Table 1.Descriptive statistics

\begin{tabular}{lll} 
& $(1)$ & $(2)$ \\
Variables & $\begin{array}{l}\text { Treated group } \\
\text { (15 stores) }\end{array}$ & $\begin{array}{l}\text { Control group } \\
\text { (29 stores) }\end{array}$ \\
\hline Percent in high income areas & 46.6 & 55.2 \\
Percent of discount stores & 53.3 & 72.4 \\
Percent of branded products on sale & 25.7 & 14.7 \\
Average daily sales (euro) & 7,949 & 10,153 \\
Average quantity of sweet and salty snacks sold per day (in & 76.54 & 110.2 \\
pieces) & & 28.16 \\
Average quantity of sweet and salty snacks sold per day (in kg.) & 19.25 & 4,230 \\
Minimum house price in the area (euro) & 4,320 & 1.36 \\
Average price per piece (euro) & 1.51 &
\end{tabular}

These data have the advantage of providing very detailed day to day information on the consumption of snacks. This advantage comes at the price of not having information on the individual characteristics of customers, including income and education, which are likely to

\footnotetext{
${ }^{4}$ According to the National Statistical Institute, 2010, about 70 percent of Italian households buy processed food in supermarkets.

${ }^{5}$ We set quantities sold to zero in a given day if the variety was available in the store on that day but did not sell and to missing if the variety was not on supply.
} 
affect the effectiveness of the treatment. On the one hand, more educated parents may have a better understanding of the aims of the School Fruit campaign and therefore reduce to a higher extent the household consumption of unhealthy snacks. On the other hand, wealthier consumers, who generally can afford an healthier diet, may react less to the program as they already eat enough fruits and vegetables and fewer snacks.

To overcame this lack of information on the characteristics of consumers, we infer socioeconomic conditions from individual choices. Different consumers select different type of stores. In particular, we expect that while wealthier individuals shop mainly in regular stores, poorer consumers buy to a larger extent in discount stores. In addition, since consumers tend to buy food products in the area where they live, we classify locations into wealthier and poorer by using local house prices ${ }^{6}$. As shown in Table 1, the percentage of discounts is 53.3 and 72.4 percent of treated and control stores respectively. Moreover, 46.6 and 55.2 percent of treated and control stores are located in wealthier areas, where house prices are above the average price in the city (and equal to $€ 4,320$ for squared meter) ${ }^{7}$.

\section{The Empirical Strategy}

According to the National Survey on the Daily Life of Italian Households (ISTAT 2009), close to 36 percent of primary school children in Italy walk to school, and the median time to cover the distance from home to school is 10 minutes. If an adult can walk on average 80 meters per minute, a child aged 6 to 11 can walk 50 meters. This suggests that a significant percentage of primary school children live within a radius of 500 meters from their primary school. Assuming that their parents shop for food in the neighbourhood, this radius can be used to classify supermarkets into two groups: the group of stores located near treated schools, and the group located relatively far from these schools. We define a supermarket as treated if it is located within the 500 meters radius of a treated school, and as control if it is located without that radius.

This classification does not require that control stores are unaffected by the policy. Rather, it assumes that treated stores are affected to a larger extent than control stores because of their proximity to affected customers. Control stores would be unaffected if: a) the households sending their children to treated primary schools shop exclusively in the neighbourhood of these schools; b) the households sending their children to untreated schools shop exclusively in stores

\footnotetext{
${ }^{6}$ House prices for different neighborhoods in the city of Rome are from the Italian Ministry of the Economy (http://www.agenziaterritorio.it/).

${ }^{7}$ Of the total 44 stores in our sample, 23 are in low income areas and 29 are discount shops; 17 of these shops are in low-income areas, which contain 4 regular shops (out of 15).
} 
outside the 500 meters radius which includes treated schools. Both conditions are unlikely to hold for all households. However, as long as shopping for food takes place mainly near the place of residence, the comparison of consumption in treated and control stores produces a lower bound estimate of the effect of the policy ${ }^{8}$.

Since our dataset covers the period from the $1^{\text {st }}$ January 2009 to the $18^{\text {th }}$ September 2011 , and the program was first implemented in February 2010, before this date none of the stores in our sample was exposed to the program. On the other hand, after February $1^{\text {st }} 2010$, treated stores were exposed to a higher extent than control stores, due to their close location to treated schools. Using a differences-in-differences approach, we estimate the causal effect of the program on the consumption of snacks by comparing the changes in the sales of snacks induced by the treatment in treated and control stores.

The program affects sales both directly and indirectly, by affecting the prices of snacks. Since the policy relevant effect is the gross effect, which combines direct and indirect effects, we exclude prices from the regressions of quantities sold on the treatment and other covariates. However, we also check whether the program has had a differential effect on the prices of snacks by running regressions of prices on treatment and covariates ${ }^{9}$. We estimate the following reduced form regression model ${ }^{10}$

$$
Y_{i j t}=\theta_{0}+\theta_{1} T_{t}+\theta_{2} T_{t}^{*} T S_{j}+\theta_{3} \text { time }_{t}+\theta_{4} \text { time }_{t} * T S_{j}+\theta_{5} X_{j t}+\gamma_{i}+\gamma_{j}+\varepsilon_{i j t}
$$

where $Y_{i j t}$ is the quantity (in pieces) of snack $i$ sold by store $j$ in day $t$; the dummy $T_{t}$ (treatment) takes the value one from February 2010 onwards and zero otherwise; the dummy $T S_{j}$ is equal to one for treated stores and to zero for control stores; time is a linear time trend; $X$ is a vector of

\footnotetext{
${ }^{8}$ In the rather extreme and implausible case when most of the shopping for food occurs far away from the place of residence, we expect to find that - if the policy is effective - the consumption of snacks declines to a higher extent in the sample of control stores.

${ }^{9}$ In Section 7 we estimate by instrumental variables a regression of quantities on prices and other covariates and find that the net effect (conditional on prices) is similar to the gross (unconditional) effect.

${ }^{10}$ Equation [1] is obtained by substituting the price equation
}

$$
P_{i j t}=\delta_{0}+\delta_{1} T_{t}+\delta_{2} T_{t} * T S_{j}+\delta_{3} \text { time }_{t}+\delta_{4} \text { time }_{t} * T S_{j}+\delta_{5} X_{j t}+v_{i j t}
$$

in the demand equation

$$
Y_{i j t}=\beta_{0}+\beta_{1} T_{t}+\beta_{2} T_{t} * T S_{j}+\beta_{3} t_{i m e}+\beta_{4} t i m e_{t} * T S_{j}+\beta_{5} X_{j t}+\beta_{6} P_{j t}+\eta_{i j t}
$$

and by adding supermarket and snack dummies. The reduced form impact of the program on the sale of snacks is equal to $\theta_{2}=\beta_{2}+\beta_{6} * \delta_{2}$. 
additional covariates - which includes total daily sales and seasonal month dummies; $\gamma_{i}$ is a set of snack dummies, $\gamma_{j}$ a set of supermarket dummies and $\varepsilon_{i j t}$ is the error term ${ }^{11}$.

Because the participation of schools to the campaign was on a voluntary basis, the allocation of stores to treatment and control groups in our data is non random. We control for time invariant unobservable store characteristics with the store fixed effects $\gamma_{j}$, and for time variant unobservables with store -specific daily sales. The key coefficient of interest is $\theta_{2}$, which measures the differential effect of the treatment on the sample of treated and control stores, or

$\theta_{2}=\left(E\left[Y_{i j t} \mid T_{t}=1, T S_{j}=1\right]-E\left[Y_{i j t} \mid T_{t}=0, T S_{j}=1\right]\right)-\left(E\left[Y_{i j t} \mid T_{t}=1, T S_{j}=0\right]-E\left[Y_{i j t} \mid T_{t}=0, T S_{j}=0\right]\right)$

where $E$ is the expectation operator. If the School Fruit campaign has been effective in reducing the consumption of snacks in the stores located near treated schools relative to the consumption in stores located farther from those schools, we should find that $\theta_{2}<0$.

\section{The Effects of the Campaign on the Sales and Prices of Snacks}

\section{6.a The Effects of the Initial Treatment}

During our sample period, the School Fruit campaign was implemented in the primary schools of Rome twice, from February 2010 to the end of school year (in June 2010) and from February 2011 to the end of school year in June 2011. Our selected sample of schools and associated supermarkets was either treated twice or never. Since the effect of the program may change over time either because individuals get used to it and, as a consequence, tend to be less affected, or because repeated treatment reinforces their response, we initially focus on the effect of the first treatment and then consider the overall response.

To investigate the effect of the initial treatment, we estimate [1] on the sub-period running from $1^{\text {st }}$ January 2009 to $31^{\text {st }}$ January 2011, just before the start of the second treatment. Table 2 reports the fixed effects estimates when the dependent variable is the number of pieces of different varieties of snacks sold by each store per day. The Table is organized in 5 columns. The first column presents the estimates for the full sample; columns (2) and (3) show separate estimates for the stores located in areas with higher than median or at most median house prices,

\footnotetext{
${ }^{11}$ In a sensitivity we have added day of the week dummies to the vector of controls. While sales increase on Saturdays, our effect of interest remains substantially unchanged.
} 
and columns (4) and (5) distinguish between regular stores in wealthier areas and other stores. In all specifications, standard errors are heteroskedasticity consistent and clustered at the store level ${ }^{12}$.

Focusing on the full sample (column (1)), our estimates show a declining trend in the daily consumption of snacks and an upward shift in consumption during the post-treatment period. The combination of these two effects imply that predicted average sales of snacks at the end of 2010 were more or less equal to average sales one year later. Compared to the control group, the sales of snacks in the treated group declined mildly (-4.6 percent) after the treatment, although the estimated difference is not statistically significant.

The statistically insignificant differences-in-differences effect could be driven by the presence of important heterogeneity in the stores included in our sample. To investigate whether this is the case, we re-estimate (1) on the two sub-samples of stores located in low income and high income areas, where the former are defined as the areas with minimum house prices below or equal to median minimum house prices, and the latter are defined as the areas with higher than median minimum house prices. As shown in columns (2) and (3), the differential effect is positive but not statistically significant in low income areas and negative and statistically significant in high income areas. This finding suggest that the School Fruit campaign has been effective in reducing the relative sales of snacks only in the treated supermarkets located in high income areas. When evaluated at sample mean average sales, this relative reduction is equal to 12 percent, a sizeable effect. Under the assumption that these stores are visited mainly by local residents, this finding suggests that the campaign has been particularly effective on high income consumers ${ }^{13}$.

Stores in wealthier areas include both regular and discount stores. Since we expect higher income consumers to shop mainly in regular stores, we distinguish between these stores in high income areas and other stores (stores in low income areas and discounts in high income areas). As shown in columns (4) and (5), the relative effect of the campaign on the consumption of unhealthy food has been negative and sizeable in the former group of shops (-12.2 percent) and close to zero in the latter group.

\footnotetext{
${ }^{12}$ The presence of serial correlation in our data requires that we cluster standard errors. We choose to cluster at the store level, as suggested by Bertrand, Duflo and Mullainathan, 2004 and Angrist and Pischke, 2009.

${ }^{13}$ Our estimates also suggest that the sale of snacks increases with total daily sales and is lowest during the summer months.
} 
Table 2. Initial treatment: February 2009 to January 2011. Quantities sold of sweet and salty snacks. Treatment group: stores located within 500 meters from treated schools. Control Group: stores distant at least 500 meters from treated schools

\begin{tabular}{|c|c|c|c|c|c|}
\hline Variables & $\begin{array}{c}(1) \\
\text { All stores }\end{array}$ & $\begin{array}{l}\text { (2) } \\
\text { Stores in high } \\
\text { income areas }\end{array}$ & $\begin{array}{c}\text { (3) } \\
\text { Stores in low } \\
\text { income areas }\end{array}$ & $\begin{array}{c}\text { (4) } \\
\text { Regular stores in } \\
\text { high income areas }\end{array}$ & $\begin{array}{l}\text { (5) } \\
\text { Other stores }\end{array}$ \\
\hline Daily sales & $\begin{array}{c}0.001^{* * * *} \\
{[0.000]}\end{array}$ & $\begin{array}{c}0.002 * * * \\
{[0.000]}\end{array}$ & $\begin{array}{c}0.001^{* * * *} \\
{[0.000]}\end{array}$ & $\begin{array}{c}0.001^{* * *} \\
{[0.000]}\end{array}$ & $\begin{array}{c}0.001^{* * *} \\
{[0.000]}\end{array}$ \\
\hline Time trend & $\begin{array}{c}-0.002^{* * *} \\
{[0.000]}\end{array}$ & $\begin{array}{c}-0.001 * * \\
{[0.000]}\end{array}$ & $\begin{array}{c}-0.003^{* * *} \\
{[0.000]}\end{array}$ & $\begin{array}{c}-0.002^{* * *} \\
{[0.000]}\end{array}$ & $\begin{array}{c}-0.003^{* * *} \\
{[0.000]}\end{array}$ \\
\hline Trend * treated & $\begin{array}{c}0.000 \\
{[0.000]}\end{array}$ & $\begin{array}{c}0.001 * * * \\
{[0.000]}\end{array}$ & $\begin{array}{c}-0.000 \\
{[0.000]}\end{array}$ & $\begin{array}{c}0.001^{* *} \\
{[0.000]}\end{array}$ & $\begin{array}{c}0.000 \\
{[0.000]}\end{array}$ \\
\hline Treatment & $\begin{array}{c}0.754 * * * \\
{[0.138]}\end{array}$ & $\begin{array}{c}0.282 \\
{[0.172]}\end{array}$ & $\begin{array}{c}0.788 * * * \\
{[0.131]}\end{array}$ & $\begin{array}{c}0.666 * * * \\
{[0.152]}\end{array}$ & $\begin{array}{c}0.798 * * * \\
{[0.174]}\end{array}$ \\
\hline Treatment $*$ treated & $\begin{array}{l}-0.110 \\
{[0.082]}\end{array}$ & $\begin{array}{c}-0.280^{* * *} \\
{[0.086]}\end{array}$ & $\begin{array}{c}0.102 \\
{[0.123]}\end{array}$ & $\begin{array}{c}-0.240 * * * \\
{[0.039]}\end{array}$ & $\begin{array}{c}-0.006 \\
{[0.115]}\end{array}$ \\
\hline $\begin{array}{l}\text { Observations } \\
\text { R-squared } \\
\text { Semi-elasticity }\end{array}$ & $\begin{array}{c}1,221,791 \\
0.374 \\
-0.0465\end{array}$ & $\begin{array}{c}612,761 \\
0.411 \\
-0.122\end{array}$ & $\begin{array}{c}572,934 \\
0.380 \\
0.0405\end{array}$ & $\begin{array}{c}334,524 \\
0.299 \\
-0.131\end{array}$ & $\begin{array}{c}855,500 \\
0.392 \\
-0.00222\end{array}$ \\
\hline
\end{tabular}

Note: each regression includes store, month and product dummies. Standard errors are clustered at the store level. One, two and three stars for statistical significance at the 10, 5 and 1 percent level of confidence.

Since wealthier individuals are more likely to buy premium products of brand manufacturers, while poorer consumers buy to a larger extent unbranded or low - brand products, we have also distinguished between varieties of snacks with a recognized national brand and with a local brand or no brand at all. Since wealthier individuals are more likely to buy premium products of brand manufacturers, while poorer consumers buy to a larger extent unbranded or low - brand products, we have also distinguished between varieties of snacks with a recognized national brand and with a local brand or no brand at all. We find (results not reported but available upon request) that the School Fruit campaign has reduced the consumption of branded varieties in treated stores relative to control stores. This reduction is statistically significant and close to 13 percent. If the preference for branded goods depends of income and education, these results confirm that wealthier consumers are relatively more affected by the campaign ${ }^{14}$.

Very similar results to those reported in Table 2 are obtained when we exclude from our sample the summer period (July and August), when schools are closed and families with children may be on vacation and live outside the treated areas (estimates not reported but available upon request). Again, we find that the School Fruit campaign has induced a reduction in the sales of

\footnotetext{
${ }^{14}$ In additional sensitivity analysis (not reported but available upon request), we have also distinguished by type of supermarket and area and estimated separate regressions for regular supermarkets in high income areas and discount supermarkets in low income areas. In line with previous results, we find a negative effect of the campaign in the former group of stores (-14.1 percent) and no significant effect in the latter group.
} 
unhealthy snacks only in the treated stores located in high income areas and in treated regular stores.

In the presence of a campaign favouring the consumption of fruit and vegetables and promoting healthy lifestyles, retailers in treated stores could have reacted to the policy by reducing the price of snacks, so as to offset the reduction in the quantities sold. Alternatively, awareness of the fact that reducing prices could not increase the consumption of informed customers, retailers could have raised prices after the treatment so as to increase revenue from customers with a low demand elasticity. We look at price behaviour in treated and control stores by estimating a version of equation [1] where the dependent variable is the price per piece sold. As shown in Table 3, there is no evidence that - relative to the control group - retail prices in treated stores have been significantly affected by the policy.

Table 3. Initial treatment, February 2009 to January 2011. Prices of sweet and salty snacks. Treatment group: stores located within 500 meters from treated schools. Control Group: stores distant at least 500 meters from treated schools.

\begin{tabular}{|c|c|c|c|c|c|}
\hline Variables & $\begin{array}{c}(1) \\
\text { All stores }\end{array}$ & $\begin{array}{l}\text { (2) } \\
\text { Stores in high } \\
\text { income areas }\end{array}$ & $\begin{array}{l}\text { (3) } \\
\text { Stores in low } \\
\text { income areas } \\
\end{array}$ & $\begin{array}{c}\text { (4) } \\
\text { Regular stores in } \\
\text { high income areas }\end{array}$ & $\begin{array}{c}(5) \\
\text { Other stores }\end{array}$ \\
\hline Daily sales & $\begin{array}{c}-0.000 \\
{[0.000]}\end{array}$ & $\begin{array}{c}0.000 * \\
{[0.000]}\end{array}$ & $\begin{array}{c}-0.000 * * * \\
{[0.000]}\end{array}$ & $\begin{array}{c}0.000 \\
{[0.000]}\end{array}$ & $\begin{array}{c}-0.000 * * * \\
{[0.000]}\end{array}$ \\
\hline Time trend & $\begin{array}{c}0.000 * * * \\
{[0.000]}\end{array}$ & $\begin{array}{c}0.000 * * * \\
{[0.000]}\end{array}$ & $\begin{array}{c}0.000 * * * \\
{[0.000]}\end{array}$ & $\begin{array}{c}0.000 * * \\
{[0.000]}\end{array}$ & $\begin{array}{c}0.000 * * * \\
{[0.000]}\end{array}$ \\
\hline Trend $*$ treated & $\begin{array}{c}0.000 \\
{[0.000]}\end{array}$ & $\begin{array}{c}0.000 \\
{[0.000]}\end{array}$ & $\begin{array}{c}-0.000 \\
{[0.000]}\end{array}$ & $\begin{array}{c}0.000 \\
{[0.000]}\end{array}$ & $\begin{array}{c}0.000 \\
{[0.000]}\end{array}$ \\
\hline Treatment & $\begin{array}{c}0.001 \\
{[0.003]}\end{array}$ & $\begin{array}{c}0.000 \\
{[0.005]}\end{array}$ & $\begin{array}{c}0.004 \\
{[0.003]}\end{array}$ & $\begin{array}{c}0.007 \\
{[0.010]}\end{array}$ & $\begin{array}{c}0.004 * \\
{[0.002]}\end{array}$ \\
\hline Treatment $*$ treated & $\begin{array}{c}0.003 \\
{[0.005]}\end{array}$ & $\begin{array}{c}0.011 \\
{[0.007]}\end{array}$ & $\begin{array}{c}-0.002 \\
{[0.003]}\end{array}$ & $\begin{array}{c}-0.002 \\
{[0.007]}\end{array}$ & $\begin{array}{c}-0.001 \\
{[0.002]}\end{array}$ \\
\hline $\begin{array}{l}\text { Observations } \\
\text { R-squared } \\
\text { Semi-elasticity }\end{array}$ & $\begin{array}{c}1,221,791 \\
0.969 \\
0.00235\end{array}$ & $\begin{array}{c}612,761 \\
0.968 \\
0.00708\end{array}$ & $\begin{array}{c}572,934 \\
0.972 \\
-0.00150\end{array}$ & $\begin{array}{c}334,524 \\
0.946 \\
-0.000978\end{array}$ & $\begin{array}{c}855,500 \\
0.977 \\
-0.000858\end{array}$ \\
\hline
\end{tabular}

Note: see Table 2

\section{6.b The Overall Response}

In this sub-section we investigate the overall effect of the treatment by estimating equation [1] on the entire period from $1^{\text {st }}$ January 2009 to $18^{\text {th }}$ September 2011. During this period, treated schools where involved twice in the School Fruit campaign, from February to the end of school 
(June) both in 2010 and in 2011. We estimate the same specifications shown in Table 2 and report our results in Table 4.

When we consider the entire sample, we find that the differential effect of the treatment on the sample of treated stores is negative, imprecisely estimated and smaller than the effect induced by the initial treatment. Smaller effects are obtained also when we divide stores according to their location (columns (2) and (3)) and type (columns (4) and (5)). In particular, we find that the relative effect of the campaign on the consumption of unhealthy food has been negative and equal to -8.2 and -6.9 percent in shops located in wealthier areas and in regular shops located in these areas.

These results suggest that the effects on the consumption of snacks induced by the initial treatment are larger than those generated by repeating the treatment. This can happen either because consumers get used to the program and pay less attention to its contents when it is repeated, or because they revert over time at least in part to their old eating habits ${ }^{15}$.

Table 4. Repeated treatment, February 2009 to September 2011. Sweet and salty snacks. Treatment group: stores located within 500 meters from treated schools. Control Group: stores distant at least 500 meters from treated schools.

\begin{tabular}{|c|c|c|c|c|c|}
\hline Variables & $\begin{array}{c}(1) \\
\text { All stores }\end{array}$ & $\begin{array}{l}\text { (2) } \\
\text { Stores in high } \\
\text { income areas }\end{array}$ & $\begin{array}{l}\text { (3) } \\
\text { Stores in low } \\
\text { income areas }\end{array}$ & $\begin{array}{c}(4) \\
\text { Regular stores } \\
\text { in high income } \\
\text { areas }\end{array}$ & $\begin{array}{c}(5) \\
\text { Discount } \\
\text { stores in low } \\
\text { income areas }\end{array}$ \\
\hline Daily sales & $\begin{array}{c}0.001 * * * \\
{[0.000]}\end{array}$ & $\begin{array}{c}0.002 * * * \\
{[0.000]}\end{array}$ & $\begin{array}{c}0.001^{* * *} \\
{[0.000]}\end{array}$ & $\begin{array}{c}0.001 * * * \\
{[0.000]}\end{array}$ & $\begin{array}{c}0.001^{* * *} \\
{[0.000]}\end{array}$ \\
\hline Time trend & $\begin{array}{c}-0.001 * * * \\
{[0.000]}\end{array}$ & $\begin{array}{c}-0.001 * * * \\
{[0.000]}\end{array}$ & $\begin{array}{c}-0.001 * * * \\
{[0.000]}\end{array}$ & $\begin{array}{c}-0.000 * * \\
{[0.000]}\end{array}$ & $\begin{array}{c}-0.001 * * * \\
{[0.000]}\end{array}$ \\
\hline Trend $*$ treated & $\begin{array}{c}0.000 \\
{[0.000]}\end{array}$ & $\begin{array}{l}0.001^{* *} \\
{[0.000]}\end{array}$ & $\begin{array}{c}-0.000 \\
{[0.000]}\end{array}$ & $\begin{array}{c}0.000 \\
{[0.000]}\end{array}$ & $\begin{array}{c}0.000 \\
{[0.000]}\end{array}$ \\
\hline Treatment & $\begin{array}{c}0.130 * * \\
{[0.049]}\end{array}$ & $\begin{array}{c}0.189 * * * \\
{[0.066]}\end{array}$ & $\begin{array}{c}0.028 \\
{[0.055]}\end{array}$ & $\begin{array}{c}0.167 * * \\
{[0.064]}\end{array}$ & $\begin{array}{c}0.116^{*} \\
{[0.058]}\end{array}$ \\
\hline Treatment $*$ treated & $\begin{array}{c}-0.087 \\
{[0.073]}\end{array}$ & $\begin{array}{c}-0.185^{* *} \\
{[0.086]}\end{array}$ & $\begin{array}{c}0.073 \\
{[0.101]}\end{array}$ & $\begin{array}{l}-0.128 * \\
{[0.063]}\end{array}$ & $\begin{array}{c}-0.040 \\
{[0.105]}\end{array}$ \\
\hline $\begin{array}{l}\text { Observations } \\
\text { R-squared } \\
\text { Semi-elasticity }\end{array}$ & $\begin{array}{c}1,581,658 \\
0.353 \\
-0.0378\end{array}$ & $\begin{array}{c}800,700 \\
0.395 \\
-0.0821\end{array}$ & $\begin{array}{c}749,131 \\
0.352 \\
0.0300\end{array}$ & $\begin{array}{c}444,711 \\
0.307 \\
-0.0693\end{array}$ & $\begin{array}{c}1,109,509 \\
0.369 \\
-0.0157\end{array}$ \\
\hline
\end{tabular}

Note: see Table 2

\footnotetext{
${ }^{15}$ To check whether the smaller effects found for repeated treatment are due to a reduction in snack prices, which may have undermined the effect of the program, we have replicated regressions reported in Table 3, considering the whole period covered by our data. Again, prices do not seem to have reacted to the treatment.
} 


\section{Sensitivity and placebo estimates}

In this section we focus on the initial treatment and verify whether our results are robust to: a) the inclusion of store - specific linear trends; b) marginal changes in the definition of the control and treatment groups. We also check the validity of our identification strategy by running a "placebo" regression of the sales of liquid detergents on the treatment and additional controls. If our empirical strategy is valid, we expect the selected treatment to affect the consumption of snacks but to have no effect whatsoever on unrelated products. Finally, we augment equation [1] with the product price of each variety. Since the latter is typically jointly determined with the quantity sold, we use an instrumental variables approach and instrument the current price of each variety with the variety - specific average price during the previous week.

\section{7.a Store specific time trends}

A typical and restrictive assumption of differences - in - differences models is common consumption trends for treated and control stores in the absence of treatment. In our empirical specification, we allow for trends to differ across the two groups of stores. A more flexible specification replaces group-specific trends with store - specific trends. This is done in Table 5, where we show that results are very similar to those obtained with group - specific trends.

Table 5. Initial treatment, February 2009 to January 2011. Sweet and salty snacks. Treatment group: stores located within 500 meters from treated schools. Control Group: stores distant at least 500 meters from treated schools. With store - specific trends

\begin{tabular}{|c|c|c|c|c|c|}
\hline Variables & $\begin{array}{c}(1) \\
\text { All stores }\end{array}$ & $\begin{array}{l}\text { (2) } \\
\text { Stores in high } \\
\text { income areas }\end{array}$ & $\begin{array}{c}\text { (3) } \\
\text { Stores in low } \\
\text { income areas }\end{array}$ & $\begin{array}{l}(4) \\
\text { Regular stores } \\
\text { in high income } \\
\text { areas } \\
\end{array}$ & $\begin{array}{l}\text { (5) } \\
\text { Discount stores in } \\
\text { low income areas }\end{array}$ \\
\hline Daily sales & $\begin{array}{c}0.001^{* * *} \\
{[0.000]}\end{array}$ & $\begin{array}{c}0.002 * * * \\
{[0.000]}\end{array}$ & $\begin{array}{c}0.001 * * * \\
{[0.000]}\end{array}$ & $\begin{array}{c}0.001 * * * \\
{[0.000]}\end{array}$ & $\begin{array}{c}0.001 * * * \\
{[0.000]}\end{array}$ \\
\hline Time trend & $\begin{array}{c}-0.002 * * * \\
{[0.000]}\end{array}$ & $\begin{array}{c}-0.001 * * \\
{[0.000]}\end{array}$ & $\begin{array}{c}-0.003^{* * *} \\
{[0.000]}\end{array}$ & $\begin{array}{c}-0.002 * * * \\
{[0.000]}\end{array}$ & $\begin{array}{c}-0.002 * * * \\
{[0.000]}\end{array}$ \\
\hline Treatment & $\begin{array}{c}0.747 * * * \\
{[0.137]}\end{array}$ & $\begin{array}{c}0.288 \\
{[0.171]}\end{array}$ & $\begin{array}{c}0.781 * * * \\
{[0.131]}\end{array}$ & $\begin{array}{c}0.668 * * * \\
{[0.151]}\end{array}$ & $\begin{array}{c}0.788 * * * \\
{[0.174]}\end{array}$ \\
\hline Treatment $*$ treated & $\begin{array}{c}-0.110 \\
{[0.082]}\end{array}$ & $\begin{array}{c}-0.284^{* * *} \\
{[0.086]}\end{array}$ & $\begin{array}{c}0.103 \\
{[0.123]}\end{array}$ & $\begin{array}{c}-0.241^{* * *} \\
{[0.040]}\end{array}$ & $\begin{array}{c}-0.003 \\
{[0.115]}\end{array}$ \\
\hline Observations & $1,221,791$ & 612,761 & 572,934 & 334,524 & 855,500 \\
\hline $\begin{array}{l}\text { R-squared } \\
\text { Semi-elasticity }\end{array}$ & $\begin{array}{c}0.375 \\
-0.0464\end{array}$ & $\begin{array}{c}0.412 \\
-0.124\end{array}$ & $\begin{array}{c}0.381 \\
0.0411\end{array}$ & $\begin{array}{c}0.299 \\
-0.132\end{array}$ & $\begin{array}{c}0.393 \\
-0.00124\end{array}$ \\
\hline
\end{tabular}

Note: see Table 2 


\section{7.b Marginal changes in the definitions of treated and control groups}

We have allocated stores to the treated and control groups depending on whether their distance from treated schools was lower or higher than a critical threshold. We have identify this threshold with 500 meters. In this sub-section, we alter this threshold in two different ways: first, we reduce it to 400 meters; second, we allocate to the control group only those stores which are distant at least 750 meters from treated schools. By choosing a lower threshold, we reduce the number of treated supermarkets (from 15 to 9); by increasing the minimum distance from treated schools, we introduce a sharper distinction between treated and control stores and reduce the number of control stores (from 29 to 18)

Table 6 presents the estimates when the threshold is 400 meters and when the control group is located at least 750 meters from treated schools. In the former case, we find that the differential effect of the treatment is negative and somewhat larger than in Table 2. There is also evidence that this effect is statistically significant only for stores located in wealthier areas, again in line with the findings of Table 2. As shown in the table, removing from the sample those stores which are located between 500 and 750 meters from treated schools have marginal effects on the relevant estimated effects, which remain negative and statistically significant for stores located in high income areas.

Table 6. Initial treatment, February 2009 to January 2011. Sweet and salty snacks. Changes in the threshold distance from treated schools.

\begin{tabular}{|c|c|c|c|c|c|}
\hline Variables & $\begin{array}{l}(1) \\
\text { All stores }\end{array}$ & $\begin{array}{l}\text { (2) } \\
\text { Stores in high } \\
\text { income areas }\end{array}$ & $\begin{array}{l}\text { (3) } \\
\text { Stores in low } \\
\text { income areas }\end{array}$ & $\begin{array}{c}(4) \\
\text { Regular stores } \\
\text { in high income } \\
\text { areas }\end{array}$ & $\begin{array}{l}(5) \\
\text { Other } \\
\text { stores }\end{array}$ \\
\hline \multicolumn{6}{|c|}{ Threshold: 400 meters } \\
\hline Treatment $*$ treated & $\begin{array}{l}-0.146 * \\
{[0.085]}\end{array}$ & $\begin{array}{c}-0.278 * * \\
{[0.098]}\end{array}$ & $\begin{array}{c}0.000 \\
{[0.147]}\end{array}$ & $\begin{array}{c}-0.199 * * * \\
{[0.053]}\end{array}$ & $\begin{array}{c}-0.078 \\
{[0.127]}\end{array}$ \\
\hline \multicolumn{6}{|c|}{$\begin{array}{l}\text { Threshold: } 750 \text { meters for } \\
\text { control stores }\end{array}$} \\
\hline Treatment $*$ treated & $\begin{array}{c}-0.055 \\
{[0.091]}\end{array}$ & $\begin{array}{c}-0.218 * * \\
{[0.091]}\end{array}$ & $\begin{array}{c}0.139 \\
{[0.143]}\end{array}$ & $\begin{array}{c}-0.242^{* * *} \\
{[0.049]}\end{array}$ & $\begin{array}{c}0.070 \\
{[0.118]}\end{array}$ \\
\hline
\end{tabular}

Note: see Table 2

\section{7.c. Placebo Regressions}


The estimated differences-in-differences effects of the School Fruit campaign on the consumption of snacks in treated stores could reflect genuine economic responses by consumers as well as placebo effects. If these effects were driving our results, we should find them also for products that are wholly unrelated to the treatment under study. To verify whether placebo effects are driving our results, we estimate Eq. (1) using liquid detergents rather than snacks as the consumption item. In the absence of these effects, sales of this product should not be affected by the campaign. As shown by Table 7, in no specification do we find evidence that the treatment has had a statistically significant differential impact on treated supermarkets. We conclude from this that our estimates of the effects of the treatment on the consumption of snacks are not a placebo effect.

Table 7. Initial treatment, February 2009 to January 2011. Liquid detergents. Treatment group: stores located within 500 meters from treated schools. Control Group: stores distant at least 500 meters from treated schools.

\begin{tabular}{|c|c|c|c|c|c|}
\hline Variables & $\begin{array}{c}(1) \\
\text { All stores }\end{array}$ & $\begin{array}{c}(2) \\
\text { Stores in high } \\
\text { income areas }\end{array}$ & $\begin{array}{c}\text { (3) } \\
\text { Stores in low } \\
\text { income areas }\end{array}$ & $\begin{array}{c}(4) \\
\text { Regular stores } \\
\text { in high income } \\
\text { areas }\end{array}$ & $\begin{array}{c}\text { (5) } \\
\text { Other stores }\end{array}$ \\
\hline Daily sales & $\begin{array}{c}0.000^{* * *} \\
{[0.000]}\end{array}$ & $\begin{array}{c}0.001 * * * \\
{[0.000]}\end{array}$ & $\begin{array}{c}0.000 * * * \\
{[0.000]}\end{array}$ & $\begin{array}{c}0.000 * * * \\
{[0.000]}\end{array}$ & $\begin{array}{c}0.000 * * \\
{[0.000]}\end{array}$ \\
\hline $\begin{array}{l}\text { Minimum local house } \\
\text { price }\end{array}$ & $-0.037 * * *$ & $-0.015^{* * *}$ & $-0.021^{* * *}$ & $-0.007^{* * *}$ & $-0.061^{* * *}$ \\
\hline Time trend & $\begin{array}{c}{[0.002]} \\
-0.002 * * * \\
{[0.000]}\end{array}$ & $\begin{array}{c}{[0.004]} \\
-0.001 * * * \\
{[0.000]}\end{array}$ & $\begin{array}{c}{[0.001]} \\
-0.002^{* *} \\
{[0.001]}\end{array}$ & $\begin{array}{c}{[0.000]} \\
-0.001 * * * \\
{[0.000]}\end{array}$ & $\begin{array}{c}{[0.008]} \\
-0.002 * * * \\
{[0.001]}\end{array}$ \\
\hline Trend * treated & $\begin{array}{c}0.000 \\
{[0.000]}\end{array}$ & $\begin{array}{l}0.000^{* *} \\
{[0.000]}\end{array}$ & $\begin{array}{l}-0.000 \\
{[0.000]}\end{array}$ & $\begin{array}{l}0.000^{*} \\
{[0.000]}\end{array}$ & $\begin{array}{l}-0.000 \\
{[0.000]}\end{array}$ \\
\hline Treatment & $\begin{array}{c}0.691 * * * \\
{[0.106]}\end{array}$ & $\begin{array}{c}0.367 * * * \\
{[0.126]}\end{array}$ & $\begin{array}{l}0.516^{* *} \\
{[0.237]}\end{array}$ & $\begin{array}{c}0.407 * * * \\
{[0.116]}\end{array}$ & $\begin{array}{c}0.712 * * * \\
{[0.173]}\end{array}$ \\
\hline Treatment * treated & $\begin{array}{c}-0.001 \\
{[0.044]}\end{array}$ & $\begin{array}{c}-0.040 \\
{[0.049]}\end{array}$ & $\begin{array}{c}0.062 \\
{[0.048]}\end{array}$ & $\begin{array}{c}-0.042 \\
{[0.065]}\end{array}$ & $\begin{array}{c}0.043 \\
{[0.037]}\end{array}$ \\
\hline $\begin{array}{l}\text { Observations } \\
\text { R-squared } \\
\text { Semi-elasticity }\end{array}$ & $\begin{array}{c}285,059 \\
0.206 \\
-0.000729\end{array}$ & $\begin{array}{c}145,443 \\
0.293 \\
-0.0441\end{array}$ & $\begin{array}{c}123,952 \\
0.153 \\
0.0739\end{array}$ & $\begin{array}{c}453,531 \\
0.307 \\
-0.0666\end{array}$ & $\begin{array}{c}1,051,804 \\
0.367 \\
0.0428\end{array}$ \\
\hline
\end{tabular}

Note: see Table 2

\section{7.d. Controlling for Product Prices}

In this final sub-section we try to decompose the total effect of the School Fruit campaign on quantities sold into the effect mediated by product prices and the net residual effect (conditional on these prices). Since current prices are jointly determined with quantities, we use an 
instrumental variable approach, which consists of instrumenting current prices with their average values during the previous week, which we treat as pre-determined with respect to current quantities. Table 8 reports our results. As expected, we find that higher prices reduce quantities sold. Perhaps more interestingly, the evidence suggests that the conditional effects of the treatment are broadly similar to the total effects estimated in Table 2. By implication, the effects mediated by price changes are very small and can be disregarded. These effects are small not because the price elasticity of demand is small - quite the contrary, estimated elasticities are above 1 in absolute value - but because prices respond very little to the treatment, as already shown in Table 3.

Table 8. Initial treatment, February 2009 to January 2011, including product prices. Sweet and salty snacks. Treatment group: stores located within 500 meters from treated schools. Control Group: stores distant at least 500 meters from treated schools. IV estimates.

\begin{tabular}{lccccc}
\hline Variables & $\begin{array}{c}(1) \\
\text { All stores }\end{array}$ & $\begin{array}{c}(2) \\
\text { Stores in high } \\
\text { income areas }\end{array}$ & $\begin{array}{c}(3) \\
\text { Stores in low } \\
\text { income areas }\end{array}$ & $\begin{array}{c}(4) \\
\text { Regular stores } \\
\text { in high income } \\
\text { areas }\end{array}$ & $\begin{array}{c}\text { Discount } \\
\text { stores in low } \\
\text { income areas }\end{array}$ \\
\hline & & & & & \\
Prices & $-2.880^{* * *}$ & $-2.068^{* * *}$ & -4.296 & $-1.781^{* * *}$ & $-4.473^{* * *}$ \\
& {$[0.495]$} & {$[0.308]$} & {$[0.903]$} & {$[0.305]$} & {$[0.815]$} \\
Daily sales & $0.001^{* * *}$ & $0.002^{* * *}$ & $0.001^{* * *}$ & $0.001^{* * *}$ & $0.001^{* * *}$ \\
& {$[0.000]$} & {$[0.000]$} & {$[0.000]$} & {$[0.000]$} & {$[0.000]$} \\
Time trend & $-0.002^{* * *}$ & $-0.001^{*}$ & $-0.002^{* *}$ & $-0.002^{* * *}$ & $-0.002^{* * *}$ \\
& {$[0.000]$} & {$[0.001]$} & {$[0.000]$} & {$[0.000]$} & {$[0.001]$} \\
Trend * treated & 0.000 & $0.001 * * *$ & -0.000 & $0.001^{* * *}$ & 0.000 \\
& {$[0.000]$} & {$[0.000]$} & {$[0.000]$} & {$[0.000]$} & {$[0.000]$} \\
Treatment & $0.734^{* * *}$ & 0.297 & 0.753 & $0.738^{* * *}$ & $0.759^{* * *}$ \\
& {$[0.138]$} & {$[0.176]$} & {$[0.129]$} & {$[0.165]$} & {$[0.172]$} \\
Treatment * treated & -0.109 & $-0.271^{* * *}$ & 0.088 & $-0.264^{* * *}$ & -0.017 \\
& {$[0.079]$} & {$[0.084]$} & {$[0.075]$} & {$[0.051]$} & {$[0.112]$} \\
Observations & 1200213 & 602572 & 564424 & 328204 & 842574 \\
R-squared & 0.384 & 0.416 & 0.399 & 0.317 & 0.403 \\
Semi-elasticity & -0.046 & -0.118 & 0.035 & -0.144 & -0.006 \\
Price elasticity & -1.798 & -1.410 & -2.330 & -1.820 & -2.230 \\
\hline
\end{tabular}

Note: see Table 2

\section{Concluding remarks}

Dietary habits and preferences largely form during childhood and hence teaching kids good habits is crucial, as they will carry these into later life. For this reason most of the projects aimed at increasing fruit and vegetable consumption are school based. However, little is known about the effects of these policies.

In this paper we have examined the impact of the European School Fruit campaign, which combines the distribution of free fruit and vegetables to school children with their education on 
the contents of an healthy diet and with different activities, including school gardening and cooking classes. Rather than evaluating the impact of the consumption of fruit and vegetables, as done by the scarce empirical literature, we have investigated whether this campaign has contributed to reduce the consumption of unhealthy junk food, which includes salty and sweet snacks and contributes to overweight and obesity problems in primary school children.

Our focus on the consumption of junk food has been guided both by data availability - we don't have information on the sale of fruit and vegetables - and by the following consideration: a campaign which increases the consumption of fruit and vegetables but has no effect on the consumption of junk food is less effective on obesity than a campaign which has a negative effect on the consumption of junk food.

We have looked at the impact of the School Fruit Scheme in the city of Rome, for which we have daily supermarket data on the sale of sweet and salty snacks. We have assigned supermarkets to treatment and control groups depending on their proximity to treated schools and we have compared the quantities sold by treated and control stores before and after the treatment. We have found that the campaign has had heterogeneous effects: on the one hand, it has substantially reduced the (relative) sale of snacks by treated stores located in high income areas; on the other hand, it has had no (statistically) significant effect on the (relative) quantities sold by stores located in low income areas.

How do we explain these heterogeneous effects? A candidate explanation is that an income effect is at work in poorer areas: as treated schools deliver free fruits and vegetables, poorer families use the saved income to buy more snacks. We find this candidate explanation difficult to believe for two reasons: first, the expected income effect is small; second, the higher real income saved by the provision of free fruit and vegetables can be devoted to buy consumption items than have nothing to do with salty and sweet snacks.

Failure to affect shops located in poorer areas could be due to policy design. For instance, some of the initiatives taken by the campaign require the availability of a computer at home, which is less likely in poorer areas. Alternatively, less well off parents living and shopping in these areas may have less time to spend with their children, and therefore may be less affected in their consumption decisions.

Finally, the policy may be effective but the research design adopted in this paper may fail to capture true effects. This would happen, for instance, if households with poor socio-economic conditions living near treated schools have a low opportunity cost of time and shop far away from their place of residence in search of better bargains. If this is the case, the reduction in the consumption of snacks would spread from treated to control stores, with no significant 
differential effect. This drawback of our research design can only be overcome by comparing consumption before and after the treatment by the households sending their children to treated and control primary schools. The household data required for such comparison must include detailed information on consumption patterns as well as information on the primary school where children go. Since these data are not currently available, we must leave this alternative research strategy to future research. 


\section{References}

Angrist J. and Pischke J., 2009, Mostly Harmless Econometrics, Princeton University Press.

Bellisle F., Dalix A., Mennen L., Galan P., Hercberg S., de Castro J.M. et al., 2003, Contribution of snacks and meals in the diet of French adults: a diet-dairy study, Physiology \& Behaviour, 79, 183-189.

Bertrand M., Duflo E. and Mullainathan S., 2004, How Much Should We Trust Differences-inDifferences Estimates?, Quarterly Journal of Economics, 119, pp. 249-275.

Bhattacharya, J., J. Currie, and S. J. Haider (2006), Breakfast of Champions? The School Breakfast Program and the Nutrition of Children and Families, Journal of Human Resources, 41(3), pp. 445-466.

Bollinger, B., Leslie, P., and Sorensen, A. (2011) Calorie posting in chain restaurants. American Economic Journal: Economic Policy, 3, pp.91-128.

Brunello, G., Fabbri, D. and Fort, M., 2012, The Causal Effect of Education on the Body Mass: Evidence from Europe forthcoming, Journal of Labor Economics

Capaci S. and Mazzocchi M., 2011, Five-a-day, a price to pay: An evaluation of the UK program impact accounting for market forces, Journal of Health Economics, 30(1), pp.87-98.

Chou, S.-Y., Grossman, M., and Saffer, H. (2004) An economic analysis of adult obesity: Results from the Behavioral Risk Factor Surveillance System. Journal of Health Economics, 23, pp. 565-587.

Cutler D. M. and Lleras-Muney A. (2010), Understanding Differences in Health Behaviors by Education, Journal of Health Economics, 29, pp.1-28.

De Sa J. and Lock K., 2008, Will European agricultural policy for school fruit and vegetables improve public health? A review of school fruit and vegetable programmes, European Journal of Public Health, 18 (6), pp.558-568.

Drichoutis, A.C., Nayga, J.R.M., and Lazaridis, P. (2009) Can nutritional label use influence body weight outcomes? Kyklos, 62, pp.500-525.

Kerr M., Rennie C., McCaffrey T., Wallace J., Hannon-Fletcher M. and Livingstone M., 2009, Snacking patterns among adolescents: a comparison of type, frequency and portion size betweenBritain in 1997 and Northern Ireland in 2005, British Journal of Nutrition, 101, 122-131.

Komlos, J., Smith, P.K., and Bogin, B. (2004) Obesity and the rate of time preference: Is there a connection? Journal of Biosocial Science 36, pp. 209-219.

ISTAT, 2009, Indagine Multiscopo sulle famiglie italiane, Rome. 
Lobstein, T., and Dibb, S. (2005) Evidence of a possible link between obesogenic food advertising and child overweight. Obesity Reviews, 6, pp.203-208.

Marques-Vidal P., Ravasco P. and Camilo M., 2006, Trends of food intake in Portugal, 19871999: results from the National Health Surveys, European Journal of Clinical Nutrition , 60, 1414-1422.

Mazzocchi M., Traill W. and Shogren J., 2009, Fat economics: nutrition, health, and economic policy, Oxford University Press.

Millimet D., Tchernis R. and Husain M., 2010, School Nutrition Programs and the Incidence of Childhood Obesity, Journal of Human Resources, 45(3), pp. 640-654.

Ovaskainen M., Reinivuo H., Tapanainen H., Hannila M., Korhonen T. and Pakkala H., 2006, Snacks as an element of energy intake and food consumption, European Journal of Clinical Nutrition, 60, pp. 494-501.

Piernas C. and Popkin B., 2010, Trends In Snacking Among U.S. Children, Health Affairs, 9(3), pp.398-404

Pomerleau, J., Lock, K., Knai, C. and McKee, M., 2005, Interventions Designed to Increase Adult Fruit and Vegetable Intake can be Effective: A Systematic Review of the Literature, Nutritional Epidemiology, 2486-96.

Schanzenbach, D.W. (2009) Do school lunches contribute to childhood obesity? Journal of Human Resources, 44, pp. 684-709.

Scharff, R.L. (2009) Obesity and hyperbolic discounting: Evidence and implications. Journal of Consumer Policy 32, pp. 3-21.

Variyam, J.N. (2008) Do nutrition labels improve dietary outcomes? Health Economics,17, pp. 695-708.

Velde S., Brug J., Wind M., Hildonen C., Bjelland M., Pe'rez-Rodrigo C. and Klepp K., 2008, Effects of a comprehensive fruit and vegetable-promoting school-based intervention in three European countries: the Pro Children Study, British Journal of Nutrition , 99, pp. 893-903 